\title{
EFEKTIVITAS STRUKTUR PENGENDALIAN INTERN DENGAN MENGGUNAKAN PENDEKATAN COSO PADA SEKRETARIAT DEWAN PERWAKILAN RAKYAT DAERAH (DPRD) KOTA MANADO
}

\author{
Chandro Novrio Tamoding ${ }^{1}$, Ventje Ilat $^{2}$, Meily Kalalo ${ }^{3}$ \\ ${ }^{1,2,3}$ Jurusan Akuntansi, Fakultas Ekonomi dan Bisnis, Universitas Sam Ratulangi, Jl. Kampus Bahu, Manado, \\ 95115, Indonesia \\ E-mail : chandro_novrio@yahoo.co.id
}

\begin{abstract}
Internal control structure is a part of internal control that is always applied in various organizations in this case the secretariat of the regional people's legislative assembly of Manado city implement internal control structure, and by using the COSO approach. The internal control structure using the COSO approach is needed to control the operational activities of the organization and aims to assess effectiveness based on the five elements of the COSO controlling component. The research method that used in this thesis research is descriptive method that is by collecting data from the research results and then describe it and attract a conclusions from the research, and the type of research used is qualitative descriptive. The results obtained that the internal control structure by using the COSO approach in secretariat of the regional people's legislative assembly of Manado city is running effectively, and the implementation of internal controls in the control of COSO based on the five elements of control has been running effectively and show its effectiveness and and implemented in accordance with the procedures of internal control and the policy of the secretary of the regional people's legislative assembly of Manado City.
\end{abstract}

Keywords: Effectiveness, Internal Control Structure, COSO.

\section{PENDAHULUAN}

Implementasi pengendalian intern merupakan bagian yang tak terpisahkan dalam rangka mencapai tujuan organisasi. Untuk seluruh organisasi pengendalian intern berlaku secara general baik organisasi yang berskala kecil maupun besar. Kebutuhan akan pengendalian intern dirasa sangat perlu ketika manusia belajar dari peristiwa-peristiwa jatuhnya perusahaan-perusahaan atau organisasi besar yang bersumber dari fraud (kecurangan). Banyaknya kecurangan-kecurangan yang timbul dan berakibat semakin kompleksnya transaksi maupun kegiatan operasional organisasi. Sehingga mengharuskan setiap organisasi untuk menerapkan struktur pengendalian intern organisasi di setiap aktivitas operasional organisasi untuk dapat terus mengalami peningkatan kinerja operasional yang berjalan efektif. Pengendalian merupakan suatu konsep yang luas yang berlaku untuk manusia, benda, situasi, dan organisasi. Pengendalian intern dilaksanakan sehingga bermanfaat untuk melindungi aset atau harta perusahaan atau organisasi dari segala jenis kesalahan penyalahgunaan sehingga memastikan bahwa kebjikan-kebijakan manajemen telah sesuai dengan peraturan atau hukum yang berlaku sehingga dapat dikatakan bahwa pengendalian intern sangat diperlukan dalam aktivitas perusahaan atau organisasi. Dalam kajian ini akan diberikan bukti langsung mengenai efektivitas struktur pengendalian intern yang diterapkan dan menilai efektivitas struktur pengendalian intern yang telah dibuat dibangun tersebut berdasarkan lima unsur komponen pengendalian COSO antara lain lingkungan pengendalian, penilaian resiko, aktivitas pengendalian, informasi dan komunikasi, dan pemantauan yang dijadikan penilaian terhadap efektivitas dalam struktur pengendalian 
intern dengan menggunakan pendekatan COSO yang di terapkan sehingga akan menunjukkan efektivitasnya dalam struktur pengendalian intern yang diterapkan atau yang telah dilaksanakan tersebut.

\section{TINJAUAN PUSTAKA}

Akuntansi. Menurut Pontoh (2013:2) akuntansi pada dasarnya akan menghasilkan informasi dari suatu informasi dari suatu sistem akuntansi yang ada dalam sebuah entitas atau organisasi yang disebut dengan informasi akuntansi dan dimanfaatkan oleh pengguna masyarakat umum, masyarakat intelektual (termasuk didalamnya mahasiswa atau peneliti) dan para pengambil keputusan bisnis dalam organisasi. Sedangkan definisi akuntansi yang dikutip dalam Jurnal Riset Akuntansi Going Concern Imbang (2018:382) Akuntansi adalah ilmu dan seni dalam melakukan pencatatan, penggolongan dan meringkas secara informatif dengan menggunakan satuan mata uang atas transaksi yang menghasilkan informasi keuangan serta interpretasinya.

Akuntansi Manajemen. Menurut Salman dan Farid (2016:2-4) Akuntansi Manajemen adalah pengembangan dan penerapan berbagai teknik pencatatan (recording), analisis, interpretasi dan presentasi, membuat perhitungan keuangan, perhitungan biaya, dan data lain yang aktif dan efektif dalam menjalakan fungsi kinerja manajerial, yaitu perencanaan, pengambilan keputusan dan pengendalian.

Pengertian Efektivitas. Menurut Irma (2012) Efektivitas adalah suatu ukuran dalam menyatakan pencapaian suatu aktivitas atau pekerjaan dalam upaya untuk mencapai tujuan yang telah ditetapkan.

Pengertian Struktur Pengendalian Intern. Menurut Mulyadi (2016:180) dan Turangan (2017:965) Struktur pengendalian intern adalah proses yang dilaksanakan untuk memberikan pemahaman tentang 3 fungsi tujuan entitas yaitu keandalan laporan keuangan, efektivitas dan efisiensi intern, dan kepatuhan terhadap hukum yang berlaku.

Pengendalian Intern. Menurut Tuanakotta (2013:127) dan Rompas (2018:223) Pengendalian intern adalah pengendalian intern dirancang, diimplementasikan dan dipelihara oleh manajemen dan karyawan lain untuk menangani resiko bisnis dan resiko kecurangan yang diketahui, seperti pelaporan keuangan yang handal.

Prinsip-Prinsip Pengendalian COSO. Menurut Committee of Sponsoring Organization of the Tradeway Commission (COSO) dalam Internal Control - Integrated Framework (2013:6-7) ada prinsip-prinsip pengendalian yaitu:

1. Lingkungan Pengendalian

a. Komitmen terhadap integritas dan nilai-nilai etis.

b. Independensi direksi terhadap manajemen dalam menjalankan tugas.

c. Membuat struktur, garis pelaporan, otorisasi dan pertanggungjawaban.

d. Komitmen pada kompetensi.

e. Mengembangkan akuntabilitas.

2. Penilaian Resiko

a. Menetapkan tujuan dengan jelas.

b. Identifikasi dan analisa risiko yang mempengaruhi pencapaian tujuan.

c. Menilai kecurangan.

d. Menganalisa perubahan yang terjadi.

3. Aktivitas Pengendalian

a. Menetapkan pengendalian.

b. Menetapkan pengendalian umum atas aktivitas teknologi.

c. Menerapkan pengendalian melalui kebijakan dan prosedur.

4. Informasi dan Komunikasi

a. Memperoleh, mendapatkan, menghasilkan, dan menggunakan informasi berkualitas. 


\section{b. Adanya komunikasi yang intern. \\ c. Adanya komunikasi yang intern.}

5. Pemantauan

a. Melaksanakan evaluasi berkala dan berkesinambungan.

b. Mengevaluasi dan mengkomunikasikan kelemahan defisiensi.

Penelitian terdahulu. Dyna (2016) dengan judul Evaluasi Sistem Pengendalian Internal Menggunakan Pendekatan COSO Studi Kasus Koperasi Warga Patra 5. Hasil penelitian menunjukkan Sistem pengendalian intern dengan menggunakan pendekatan COSO sudah berjalan dengan baik dan cukup memadai. Tontoli, Elim, dan Tirayoh (2018) dengan judul Analisis Efektivitas Pengendalian Intern Persediaan Barang Dagang Pada PT. Kimia Farma Apotek 74 Manado. Hasil penelitian menunjukkan bahwa pelaksanaan pengendalian intern persediaan barang dagangan yang diterapkan oleh PT. Kimia Farma telah efektif.

\section{METODE PENELITIAN}

Jenis Penelitian. Penulis menggunakan jenis penelitian deskriptif kualitatif sebagai dasar untuk mengetahui efektivitas struktur pengendalian intern dengan menggunakan pendekatan COSO pada Sekretariat Dewan Perwakilan Rakyat Daerah (DPRD) Kota Manado.

Tempat dan Waktu Penelitian. Penelitian dilakukan di Sekretariat Dewan Perwakilan Rakyat Daerah (DPRD) Kota Manado bertempat di J1. Balai Kota No.1 Wenang, Kota Manado, Sulawesi Utara. Waktu penelitian dimulai pada bulan April 2018 sampai bulan Mei 2018.

Metode Pengumpulan data. Jenis data dalam penelitian ini menggunakan jenis data kualitatif sebagai dasar atau acuan untuk mengetahui efektivitas struktur pengendalian intern dengan menggunakan pendekatan COSO (Committee of Sponsoring Organization of the Tradeway Commission) pada Sekretariat Dewan Perwakilan Rakyat Daerah (DPRD) Kota Manado. Sumber data dalam penelitian ini adalah data primer yaitu berupa wawancara, jajak pendapat dengan individu-individu yang berada di Sekretariat Dewan Perwakilan Rakyat Daerah (DPRD) Kota Manado, mengenai efektivitas struktur pengendalian intern dengan menggunakan pendekatan COSO (Committee of Sponsoring Organization of the Tradeway Commission) pada Sekretariat Dewan Perwakilan Rakyat Daerah (DPRD) Kota Manado.

Teknik Pengumpulan Data. Teknik pengumpulan menggunakan antara lain:

1. Wawancara. Penelitian ini mewawancarai langsung pihak-pihak yang terkait yaitu Sekretaris Dewan Perwakilan Rakyat Daerah (DPRD) Kota Manado, Bagian keuangan meliputi Kabag keuangan, Kasubag program dan anggaran, dan Kasubag pembukuan dan pelaporan Sekretariat Dewan Perwakilan Rakyat Daerah (DPRD) Kota Manado.

2. Dokumentasi. Pengumpulan data diperoleh dari catatan-catatan yang dimiliki sekretariat. Dokumentasi digunakan untuk memperoleh data mengenai efektivitas struktur pengendalian intern dengan menggunakan pendekatan COSO (Committee of Sponsoring Organization of the Tradeway Commission) pada Sekretariat Dewan Perwakilan Rakyat Daerah (DPRD) Kota Manado.

3. Studi Kepustakaan. Data dikumpulkan dari buku, dan laporan-laporan yang berhubungan dengan penelitian.

Metode dan Proses Analisis. Metode yang digunakan adalah metode analisis deskriptif. Metode analisis deskriptif adalah metode yang bertujuan untuk mendeskripsikan atau menggambarkan dan menerangkan data yang kemudian diolah sehingga dapat membuat suatu kesimpulan berdasarkan informasi dan data yang berhasil dikumpulkan. Proses analisis yang dilakukan adalah:

1. Tahap pertama, penulis mengumpulkan data melalui kegiatan wawancara yang dilakukan kepada Sekretaris Dewan Perwakilan Rakyat Daerah (DPRD) Kota Manado dan juga 
mewawancarai Bagian keuangan meliputi Kabag keuangan, Kasubag program dan anggaran, dan Kasubag pembukuan dan pelaporan Sekretariat Dewan Perwakilan Rakyat Daerah (DPRD) Kota Manado serta mengumpulkan data dari dokumentasi yaitu catatancatatan yang dimiliki sekretariat dan studi kepustakaan.

2. Tahap kedua, penulis membahas hasil data wawancara yang dilakukan untuk mengetahui efektivitas struktur pengendalian intern dengan menggunakan pendekatan COSO (Committee of Sponsoring Organization of the Tradeway Commission) serta membahas hasil data dari catatan-catatan sekretariat dan studi kepustakaan.

3. Tahap ketiga, penulis mengidentifikasi struktur pengendalian intern dengan menggunakan pendekatan COSO (Committee of Sponsoring Organization of the Tradeway Commission) berdasarkan kelima unsur komponen pengendalian sebagai acuan dalam mengetahui efektivitas dari struktur pengendalian intern berdasarkan hasil wawancara yang dilaksanakan dengan Sekretaris Dewan Perwakilan Rakyat Daerah (DPRD) Kota Manado dan juga mewawancarai Bagian keuangan meliputi Kabag keuangan, Kasubag program dan anggaran, dan Kasubag pembukuan dan pelaporan Sekretariat Dewan Perwakilan Rakyat Daerah (DPRD) Kota Manado dan membuat tabel untuk menunjukan efektivitas struktur pengendalian intern dengan menggunakan pendekatan COSO berdasarkan kelima komponen pengendalian COSO.

4. Tahap keempat, penulis menarik kesimpulan mengenai efektivitas struktur pengendalian intern dengan menggunakan pendekatan COSO untuk mengetahui efektivitas dari struktur pengendalian intern dengan menggunakan pendekatan COSO.

5. Tahap kelima, penulis memberikan saran kepada sekretariat mengenai efektivitas struktur pengendalian intern dengan menggunakan pendekatan COSO (Committee of Sponsoring Organization of the Tradeway Commission).

\section{HASIL ANALISIS DAN PEMBAHASAN}

1. Hasil Analisis

\section{Pendekatan COSO Di Sekretariat Dewan Perwakilan Rakyat Daerah (DPRD)}

Kota Manado.

Berdasarkan data yang diperoleh dari hasil wawancara, catatan-catatan sekretariat dan studi kepustakaan yang dilakukan maka Pendekatan COSO (Committee of Sponsoring Organization of the Tradeway Commission) Sekretariat Dewan Perwakilan Rakyat Daerah (DPRD) Kota Manado berdasarkan kelima unsur adalah sebagai berikut:

Tabel 4.1

Komponen Pengendalian COSO (Committee of Sponsoring Organization of the Tradeway Commission)

5 Komponen Pengendalian COSO

1. Lingkungan Pengendalian (Control Environment)

2. Penilaian Resiko (Risk Assessment)

3. Aktivitas Pengendalian (Control Activities)

4. Informasi dan Komunikasi (Information and Communication), dan

5. Pemantauan (Monitoring)

Sumber : COSO (2013)

1. Lingkungan Pengendalian (Control Environment)

a. Organisasi yang terdiri dari Sekretaris Dewan Perwakilan Rakyat Daerah (DPRD)

Kota Manado, 4 Kepala Bagian, 11 Kepala Sub Bagian Staff, dan Pegawai ASN (Aparatur Sipil Negara) telah menunjukkan komitmen terhadap integritas dan nilainilai etika. Sekretaris Dewan Perwakilan Rakyat Daerah (DPRD) Kota Manado, 4 
Kepala Bagian, 11 Kepala Sub Bagian, Staff, dan Pegawai ASN telah menunjukkan integritas dan nilai-nilai etika yang baik, dengan dilakukannya tindakan penegakan hukuman disiplin terhadap pegawai ASN yang melanggar nilai-nilai etika dan integritas berdasarkan PP No. 53 Tahun 2010 tentang hukuman disiplin pegawai negeri sipil.

b. Sekretaris menunjukkan independensi dalam mengawasi pengembangan dan penerapan struktur pengendalian intern. Dalam pelaksanaanya Sekretaris melakukan sikap profesionalisme yaitu dengan memperoleh informasi dan mengawasi proses pelaporan keuangan serta pengendalian intern dalam organisasi terhadap kepatuhan atas peraturan perundang-undangan dan sikap ketelitian mengenai penerapan struktur pengendalian intern di Sekretariat DPRD Kota Manado.

c. Kabag dan Kasubag dengan pengawasan Sekretaris Dewan Perwakilan Rakyat Daerah (DPRD) Kota Manado membuat struktur, jalur-jalur dalam pelaporan, dan tanggung jawab dalam melaksanakan tugas. Dalam pelaksanaanya Sekretariat Dewan Perwakilan Rakyat Daerah (DPRD) Kota Manado melakukannya sesuai dengan standar operasional prosedur PP. 71 Tahun 2010.

d. Organisasi menunjukkan komitmen yaitu menarik, mengembangkan, dan mempertahankan Aparatur Sipil Negara (ASN) yang kompeten sejalan dengan tujuan Sekretariat Dewan Perwakilan Rakyat Daerah (DPRD) Kota Manado. Dalam pelaksanaannya Sekretaris Dewan Perwakilan Rakyat Daerah (DPRD) Kota Manado mengembangkan keahlian, keterampilan dan mengkondisikan Aparatur Sipil Negara (ASN) untuk mengikuti kegiatan-kegiatan Diklat (Pendidikan dan Pelatihan), Workshop, Bimtek (Bimbingan Teknis), serta kegiatan training lainnya. Jika Aparatur Sipil Negara (ASN) melaksanakan tugas dan tanggung jawab sebagai Aparatur Sipil Negara (ASN) dengan baik maka akan diberikan reward penaikan pangkat atau golongan dan bisa menjadi pejabat pemerintah. Untuk mempertahankan Aparatur Sipil Negara (ASN) maka dilihat dari cara kinerjanya yang baik dan taat pada hukum yang berlaku sesuai dengan PP. No. 5 Tahun 2014 mengenai Aparatur Sipil Negara (ASN).

e. Organisasi meyakinkan individu dalam hal ini Aparatur Sipil Negara (ASN) untuk melaksanakan tugas dan tanggung jawab dalam struktur pengendalian intern. Dalam pelaksanaanya Sekretariat Dewan Perwakilan Rakyat Daerah (DPRD) Kota Manado melaksanakannya kepada setiap Aparatur Sipil Negara (ASN) berkewajiban untuk membuat laporan kinerja sesuai dengan sasaran kinerja dan dokumen perjanjian kinerja yang didukung juga oleh aturan yang mengatur tentang tugas dan fungsi Peraturan Walikota (Perwako) No.34 Tahun 2016.

2. Penilaian Resiko (Risk Assessment)

a. Organisasi menetapkan tujuan yang jelas untuk mengidentifikasi dan menilai resiko yang berkaitan dengan struktur pengendalian intern. Sekretariat Dewan Perwakilan Rakyat Daerah (DPRD) Kota Manado sudah menetapkan tujuan dengan jelas dalam mengidentifikasi dan menilai dengan baik dan telah dilaksanakan dengan baik serta menyusun tujuan organisasi yang dirangkum dalam rencana strategi 5 tahunan Sekretariat Dewan Perwakilan Rakyat Daerah (DPRD) Kota Manado berdasarkan isuisu strategis sehingga identifikasi maupun pengendalian dan penilaian resiko yang berkaitan dengan struktur pengendalian intern sehingga dapat terdefinisi dengan jelas.

b. Organisasi mengidentifikasi resiko terhadap pencapaian tujuan diseluruh entitas dan analis resiko sebagai dasar untuk menentukan bagaimana resiko harus dikelola. Dalam mengidentifikasi resiko dan mengelola resiko, Sekretariat Dewan Perwakilan Rakyat Daerah (DPRD) Kota Manado melakukan rapat koordniasi antar bagian secara 
berkala untuk menilai resiko, menganalisis resiko, maupun mensolusikan terhadap masalah-masalah yang teridentifikasi serta mengelola resiko.

c. Organisasi harus mempertimbangkan potensi kecurangan dalam menilai resiko terhadap struktur pengendalian intern. Dalam mempertimbangkan potensi kecurangan dalam menilai resiko terhadap struktur pengendalian intern Sekretariat Dewan Perwakilan Rakyat Daerah (DPRD) Kota Manado menggunakan lackcoordination, overlapping pekerjaan, perangkapan pekerjaan perangkapan jabatan dalam mempertimbangkan potensi kecurangan dalam menilai resiko terhadap struktur pengendalian intern.

d. Organisasi mengidentifikasi dan menilai perubahan signifikan yang dapat mempengaruhi struktur pengendalian intern. Setiap perubahan yang terjadi pada Sekretariat Dewan Perwakilan Rakyat Daerah (DPRD) Kota Manado dikontrol dengan baik dengan cara dilakukan evaluasi per bagian- bagian yang dilakukan secara berkala. Jika terjadi perubahan diakibatkan karena intervensi politik.

e. Organisasi melakukan penilaian resiko terkait kecurangan pelaporan keuangan, pelanggaran, potensi kerugian aset dan korupsi. Sekretariat Dewan Perwakilan Rakyat Daerah (DPRD) Kota Manado melakukan penilaian resiko terkait kecurangan pelaporan keuangan, pelanggaran, potensi kerugian aset dan korupsi dengan cara melakukan penilaian melalui PP. 71 Tahun 2010 tentang sistem akuntansi pemerintahan berbasis akrual jika terjadi korupsi dan pelanggaran akan dilaksanakan proses melalui jalur hukum.

3. Aktivitas Pengendalian (Control Activities)

a. Organisasi melaksanakan pengembangan pengendalian yang berkontribusi terhadap aktivitas pengendalian resiko dalam struktur pengendalian intern. Aktivitas pengendalian dalam struktur pengendalian intern pada Sekretariat Dewan Perwakilan Rakyat Daerah (DPRD) Kota Manado sudah dilakukan dengan baik dalam hal ini melakukan semua kegiatan tugas dan fungsi dari Sekretariat Dewan Perwakilan Rakyat Daerah (DPRD) Kota Manado dilakukan berdasarkan SOP (Standar Operasional Prosedur, SPM (Standar Pelayanan Minimal) dan maupun peraturan perundang-undangan lainnya yang berhubungan dengan proses yang diterapkan yaitu otorisasi, persetujuan, perbandingan jumlah fisik rekonsiliasi dan pengawasan.

b. Organisasi memilih dan mengembangkan aktivitas pengendalian atas teknologi untuk mendukung struktur pengendalian intern. Aktivitas pengendalian atas teknologi yang dilaksanakan pada Sekretariat Dewan Perwakilan Rakyat Daerah (DPRD) Kota Manado yaitu dengan memilih dan mengembangkan sistem pengendalian berbasis teknologi informasi dan komunikasi yang terintegrasi dengan command centre manado (pusat perintah) yaitu berupa backup aplikasi, database dan sistem operasi.

c. Organisasi menyalurkan pengendalian terhadap kebijakan-kebijakan berdasarkan dengan SOP (Standar Operasional Prosedur). Dalam hal ini prosedur-prosedur tindakan pengendalian Sekretariat Dewan Perwakilan Rakyat Daerah (DPRD) Kota Manado yaitu dengan melakukan rapat koordinasi dan evaluasi secara berkala mengenai kebijakan pengevaluasian mengenai laporan keuangan.

d. Organisasi memiliki personil yang tepat dalam proses perancangan dan pengendalian untuk menangani resiko yang teridentifikasi. Sekretariat Dewan Perwakilan Rakyat Daerah (DPRD) Kota Manado memiliki personil yang tepat dalam proses perancangan dan pengendalian dalam menangani resiko yang teridentifikasi yaitu bagian keuangan dan Sekretaris DPRD.

e. Organisasi mempertimbangkan efektivitas pengendalian ketika mengevaluasi resiko yang diidentifikasi. Sekretariat Dewan Perwakilan Rakyat Daerah (DPRD) Kota Manado mempertimbangkan sifat kesalahan yang teridentifikasi, tindak lanjut yang 
memadai dalam memproses perbedaan atau kesalahan yang teridentifikasi, dan bukti untuk memastikan pengendalian telah beroperasi dengan baik berdasarkan standar operasional yang diterapkan di Sekretariat Dewan Perwakilan Rakyat Daerah (DPRD) Kota Manado.

4. Informasi dan Komunikasi (Information and Communication)

a. Organisasi memakai informasi berkualitas, relevan dalam mendukung struktur pengendalian intern. Dalam memperoleh informasi yang berkualitas dalam struktur pengendalian intern Sekretariat Dewan Perwakilan Rakyat Daerah (DPRD) Kota Manado menghasilkan informasi dan menggunakan informasi yang berkualitas dan relevan dengan mengupdate informasi berdasarkan peraturan-peraturan yang baru serta isu-isu akrual yang berkembang ditengah masyarakat maupun penyelenggaraan pemerintahan dengan memanfaatkan media online maupun media cetak.

b. Organisasi secara intern memberikan informasi termasuk tujuan dan tanggung jawab pengendalian intern dalam rangka mendukung tujuan pengendalian intern. Sekretaris Dewan Perwakilan Rakyat Daerah (DPRD) Kota Manado secara rutin dan berkala memberikan informasi dan mengkomunikasikan kepada Kabag, Kasubag, Staf dan Aparatur Sipil Negara (ASN) dengan informasi yang dijalankan dengan garis koordinasi dan komando kepada bagian-bagian Sekretariat Dewan Perwakilan Rakyat Daerah (DPRD) Kota Manado dengan menggunakan dan memanfaatkan teknologi informasi komunikasi berdasarkan tujuan laporan keuangan dengan jelas sehingga semua pihak memahami peran masing-masing dalam Sekretariat Dewan Perwakilan Rakyat Daerah (DPRD) Kota Manado.

c. Organisasi berinteraksi dengan pihak ekstern dan mengkomunikasikan pengendalian intern. Dalam pelaksanaan struktur pengendalian intern Sekretariat Dewan Perwakilan Rakyat Daerah (DPRD) Kota Manado menyediakan media komunikasi dengan pihak eksternal melalui jalur penjaringan aspirasi, kegiatan turun lapangan maupun kegiatan cinteraksi dengan masyarakat.

d. Organisasi secara berkala meninjau kualitas informasi untuk menilai keandalan dan ketetapan waktu. Sekretariat Dewan Perwakilan Rakyat Daerah (DPRD) Kota Manado meninjau kualitas informasi untuk menilai keandalan dan ketetapan waktu berdasarkan pembuatan laporan keuangan, ataupun perubahan-perubahan yang diperbaiki terkait dengan koreksi terhadap laporan keuangan serta menilai keandalan laporan keuangan berdasarkan ketepatan waktu yang dibuat.

e. Organisasi menetapkan kebutuhan informasi untuk mendukung struktur pengendalian intern yang efektif pada tingkat yang relevan dan spesifik. Dalam mendukung kegiatan pengendalian internal yang efektif pada tingkat yang relevan dan spesifik, Sekretariat Dewan Perwakilan Rakyat Daerah (DPRD) Kota Manado dalam hal ini Sekretaris DPRD bersama-sama dengan Anggota DPRD dan Pimpinan DPRD berkoordinasi terkait dengan pelaksanaan struktur pengendalian intern dan mendukung pelaksanaan struktur pengendalian intern yang efektif pada tingkat yang relevan dan spesifik mengenai efektivitas struktur pengendalian intern serta mengevaluasi pelaksanann struktur pengendalian intern.

5. Pemantauan (Monitoring)

a. Organisasi secara intern melaksanakan pengawasan dalam pengendalian intern. Pelaksanaan pengawasan pengendalian intern pada Sekretariat Dewan Perwakilan Rakyat Daerah (DPRD) Kota Manado yaitu melakukan kegiatan rapat evaluasi dan koordinasi setiap bulan dan rapat kerja rutin setiap minggu.

b. Organisasi melaksanakan evaluasi pada saat melakukan pemonitoran dalam pengendalian intern. Evaluasi dalam pengawasan pengendalian intern pada Sekretariat 
Dewan Perwakilan Rakyat Daerah (DPRD) Kota Manado dilakukan bersamaan dengan kegiatan monitoring.

c. Organisasi melakukan pemonitoran dan melaporkan hasil pemonitoran untuk meminimalkan resiko. Sekretariat Dewan Perwakilan Rakyat Daerah (DPRD) Kota Manado melakukan pemonitoran dari setiap hasil monitoring dilaporkan berdasarkan garis koordinasi untuk meminimalkan resiko.

d. Organisasi menilai kontrol dengan menggunakan pendekatan COSO (Committee of Sponsoring Organization of the Tradeway Commission) berdasarkan lima unsur komponen pengendalian. Sekretariat Dewan Perwakilan Rakyat Daerah (DPRD) Kota Manado menilai kontrol dengan menggunakan pendekatan COSO berdasarkan lima unsur komponen pengendalian yang menunjukkan efektivitas dari struktur pengendalian intern yang diterapkan.

e. Organisasi menggunakan hasil audit sebagai bagian dari program pemantauan. Sekretariat Dewan Perwakilan Rakyat Daerah (DPRD) Kota Manado menggunakan hasil audit sebagai bagian dari pemantauan karena hasil audit dapat menunjukkan efektivitas dari struktur pengendalian intern yang berjalan efektif dan menunjukkan efektivitasnya.

\subsection{Pembahasan}

Struktur pengendalian intern dengan menggunakan pendekatan COSO (Committee of Sponsoring Organization of the Tradeway Commission) berpengaruh penting terhadap aktivitas operasional organisasi. Dari penelitian yang dilakukan diperoleh penjelasan bahwa Sekretariat Dewan Perwakilan Rakyat Daerah (DPRD) sudah menunjukan efektivitasnya pada struktur pengendalian intern yang diterapkan meliputi struktur organisasi yang sudah terstruktur dengan baik dan pelaksaanan tugas-tugas masing-masing struktur telah berjalan dengan baik dan efektif, metode pencatatan yang dilakukan dengan menggunakan metode pencatatan periodik sudah berjalan efektif, penyusunan laporan keuangan dan pelaporan keuangan Dewan Perwakilan Rakyat Daerah (DPRD) Kota Manado sudah berdasarkan PP. 71 Tahun 2010 tentang sistem akuntansi pemerintahan berbasis akrual yaitu berupa laporan realisasi anggaran, laporan perubahan saldo, anggaran lebih, neraca, laporan operasional, laporan arus kas dan laporan perubahan ekuitas sudah berjalan efektif dan pelaporan keuangan serta penyusunan laporan keuangan dipercaya, andal dan tidak terjadi tindakan kecurangan atau fraud, kebijakan manajemen dalam mendorong efisiensi kepatuhan sudah berjalan efektif.

Pendekatan COSO (Committee of Sponsoring Organization of the Tradeway Commission) yang dilakukan berdasarkan kelima unsur komponen pengendalian yaitu, Lingkungan Pengendalian (Control Environment) menjelaskan organisasi yang terdiri dari Sekretaris Dewan Perwakilan Rakyat Daerah (DPRD) Kota Manado, 4 Kepala Bagian, 11 Kepala Sub Bagian Staff, dan Pegawai ASN (Aparatur Sipil Negara) telah menunjukkan komitmen terhadap integritas dan nilai-nilai etika, organisasi mengawasi dan menerapkan struktur pengendalian intern, Kabag dan Kasubag dengan pengawasan Sekretaris Dewan Perwakilan Rakyat Daerah (DPRD) Kota Manado membuat struktur, jalur-jalur pelaporan, wewenang-wewenang dan tanggung jawab dalam melaksanakan tugas, organisasi menunjukkan komitmen yaitu menarik, mengembangkan, dan mempertahankan individu yang kompeten sejalan dengan tujuan Sekretariat Dewan Perwakilan Rakyat Daerah (DPRD) Kota Manado, organisasi meyakinkan individu dalam hal ini Aparatur Sipil Negara (ASN) untuk melaksanakan tugas dan tanggung jawab dalam struktur pengendalian intern.

Penilaian Resiko (Risk Assessment), menjelaskan organisasi menetapkan tujuan yang jelas untuk mengidentifikasi dan menilai resiko yang berkaitan dengan struktur pengendalian intern, organisasi mengidentifikasi resiko terhadap pencapaian tujuan diseluruh entitas dan analis resiko sebagai dasar untuk menentukan bagaimana resiko harus dikelola, organisasi 
harus mempertimbangkan potensi kecurangan dalam menilai resiko terhadap struktur pengendalian intern, organisasi mengidentifikasi dan menilai perubahan yang signifikan yang dapat mempengaruhi struktur pengendalian intern serta organisasi melakukan penilaian resiko terkait kecurangan pelaporan keuangan, pelanggaran, potensi kerugian aset dan korupsi.

Aktivitas Pengendalian (Control Activities), menjelaskan mengembangkan aktivitas pengendalian yang berkontribusi terhadap pengendalian resiko dalam struktur pengendalian intern, organisasi memilih dan mengembangkan aktivitas pengendalian atas teknologi untuk mendukung struktur pengendalian intern, organisasi menyebarkan aktivitas pengendalian melalui kebijakan-kebijakan yang berdasarkan dengan SOP (Standar Operasional Prosedur), organisasi memiliki personil yang tepat dalam proses perancangan dan pengendalian untuk menangani resiko yang teridentifikasi dan organisasi mempertimbangkan efektivitas pengendalian ketika mengevaluasi resiko yang diidentifikasi.

Informasi dan Komunikasi (Information and Communication), organisasi memakai informasi berkualitas, relevan dalam mendukung struktur pengendalian intern, organisasi secara intern memberikan informasi termasuk tujuan dan tanggung jawab pengendalian intern dalam rangka mendukung tujuan pengendalian intern, termasuk tujuan dan tanggung jawab pengendalian intern dalam rangka mendukung tujuan pengendalian intern, organisasi berinteraksi dengan pihak ekstern dan mengkomunikasikan pengendalian intern, organisasi secara berkala meninjau kualitas informasi untuk menilai keandalan dan ketetapan waktu dan organisasi menetapkan kebutuhan informasi untuk mendukung struktur pengendalian intern yang efektif pada tingkat yang relevan dan spesifik.

Pemantauan (Monitoring), menjelaskan organisasi secara intern melaksanakan pengawasan dalam pengendalian intern, organisasi melaksanakan evaluasi pada saat melakukan pemonitoran dalam pengendalian intern, organisasi melakukan pemonitoran dan melaporkan hasil pemonitoran untuk meminimalkan resiko, organisasi menilai kontrol dengan menggunakan pendekatan COSO berdasarkan lima unsur komponen pengendalian, dan organisasi menggunakan hasil audit sebagai bagian dari program pemantauan.

SPAP (Standar Profesional Akuntan Publik) yang di terapkan di Sekretariat Dewan Perwakilan Rakyat Daetah (DPRD) Kota Manado mengacu pada standar akuntansi publik PP. 71 Tahun 2010 tentang standar akuntansi pemerintahan sesuai dengan tentang penerapan standar akuntansi berbasis akrual pada pemerintah daerah. Standar-standar pelaporan audit sudah sesuai dengan prosedur yang ditetapkan di Sekretariat DPRD Kota Manado dan standar-standar pelaporan audit di Sekretariat DPRD Kota Manado mengacu pada PP. No. 60 Tahun 2008 tentang Struktur Pengendalian Intern Pemerintah (SPIP).

Penyusunan anggaran di Sekretariat Dewan Perwakilan Rakyat Daerah (DPRD) Kota Manado telah berdasarkan PP. 71 Tahun 2010 yaitu anggaran belanja langsung dan anggaran belanja tidak langsung. Anggaran belanja langsung berupa anggaran belanja pegawai, anggaran belanja barang dan jasa, dan anggaran belanja modal, sedangkan anggaran belanja tidak langsung berupa tunjangan gaji pegawai serta rencana-rencana biaya dalam penyusunan anggaran berupa rencana biaya kerja dan rencana biaya anggaran sudah sesuai dengan sistem akuntansi pemerintahan berbasis akrual dan sudah melalui proses penyusunan anggaran sehingga tidak ditemukan penyimpangan kecurangan atau fraud.

Pembukuan atau pertanggungjawaban keuangan DPRD dan Sekretariat Dewan Perwakilan Rakyat Daerah (DPRD) Kota Manado telah berdasarkan PP. 71 Tahun 2010 tentang sistem akuntansi pemerintahan berbasis akrual yaitu mengenai pemeriksaan anggaran, perhitungan anggaran, perbaikan anggaran, pemindahan anggaran, realiasasi belanja rutin dan pembangunan, meneliti surat pertanggungjawaban (SPJ) tentang pelaksanaan APBD, dan menyiapkan bahan pengesahan surat pertanggungjawaban (SPJ) keuangan belanja rutin dan pembangunan serta belanja pegawai sudah berdasarkan standar 
operasional prosedur yang di terapkan, dan telah sesuai dengan standar operasional prosedur yang berlaku di Sekretariat Dewan Perwakilan Rakyat Daerah (DPRD) Kota Manado.

Administrasi keuangan Sekretariat Dewan Perwakilan Rakyat Daerah (DPRD) Kota Manado telah berdasarkan PP. 71 Tahun 2010 tentang sistem akuntansi pemerintahan berbasis akrual yaitu yaitu mengenai pembayaran gaji pegawai, Sekretaris, Anggota DPRD, dan Pimpinan DPRD serta tunjangan-tunjangan lainnya. Pelaksanaannya dilakukan oleh Sekretaris DPRD berdasarkan standar operasional prosedur yang di terapkan. Berdasarkan hasil penelitian dan pembahasan menunjukkan bahwa struktur pengendalian intern dengan menggunakan pendekatan COSO (Committee of Sponsoring Organization of the Tradeway Commission) pada Sekretariat Dewan Perwakilan Rakyat Daerah (DPRD) Kota Manado telah berjalan efektif dan telah menunjukkan efektivitasnya.

\section{KESIMPULAN DAN SARAN}

\subsection{Kesimpulan}

Berdasarkan hasil penelitian dan pembahasan yang telah di kemukakan sebelumnya maka dapat diambil kesimpulan bahwa struktur pengendalian intern dengan pendekatan COSO pada Sekretariat Dewan Perwakilan Rakyat Daerah (DPRD) Kota Manado telah berjalan efektif didukung oleh:

1. Struktur organisasi telah berjalan efektif, metode pencatatan telah berjalan efektif, pelaporan keuangan penyusunan laporan keuangan andal dan dipercaya, kebijakan manajemen dalam mendorong efesiensi kepatuhan kebijakan telah berjalan secara efektif serta standar professional akuntan publik, standar pelaporan audit, penyusunan anggaran, pembukuan dan pertanggung jawaban keuangan dan administrasi keuangan telah berjalan secara efektif berdasarkan pengendalian intern yang di terapkan.

2. Pengendalian COSO berdasarkan kelima unsur komponen pengendalianyang dilaksanakan di Sekretariat Dewan Perwakilan Rakyat Daerah (DPRD) Kota Manado yaitu lingkungan pengendalian (control environment) telah berjalan efektif, penilaian resiko (risk assessment) telah berjalan efektif, aktivitas pengendalian (control activities) telah berjalan secara efektif, informasi dan komunikasi (information and communication) teah berjalan efektif, pemantauan (monitoring) telah berjalan efektif.

3. Sekretaris Dewan Perwakilan Rakyat Daerah (DPRD) Kota Manado bersama-sama dengan Kabag (Kepala bagian), dan Kasubag (Kepala sub bagian), serta Staf dan ASN (Aparatur Sipil Negara) telah menjalankan tugasnya dengan ketetentuan yang berlaku, dan sesuai dengan pendekatan COSO pada Sekretariat Dewan Perwakilan Rakyat Daerah (DPRD) Kota Manado telah berjalan efektif dan dapat dikatakan struktur pengendalian intern dengan menggunakan pendekatan COSO pada Sekretariat Dewan Perwakilan Rakyat Daerah (DPRD) Kota Manado telah menunjukkan efektivitasnya.

\subsection{Saran}

Sesuai dengan hasil penelitian dan analisis yang dilakukan sebelumnya, maka Sekretariat Dewan Perwakilan Rakyat Daerah (DPRD) Kota Manado perlu untuk mempertahankan dan meningkatkan efektivitas struktur pengendalian intern dengan menggunakan pendekatan COSO (Committee of Sponsoring Organization of the Tradeway Commission). 


\section{DAFTAR PUSTAKA}

COSO (Committee of Sponsoring Organization of the Tradeway Commission). 2013. Internal Control - Integrated Framework : Executive Summary. North Carolina.

Irma, Indra. 2012. Analisis Efektivitas Struktur Pengendalian Intern Dalam Upaya Menekan Terjadinya Kredit Macet Pada Lembaga Perkreditan Desa SE-Kabupaten Buleleng. Skripsi (Online). Fakultas Ekonomi Universitas Udayana Denpasar.

Imbang, M., Pontoh, W., dan Gamaliel, H. 2018. Analisis Perlakuan Akuntansi Atas Pengelolaan Beras Sejahterah Pada Perum Bulog Divre Sulawesi Utara dan Gorontalo. Jurnal Riset Akuntansi Going Concern Vol. 13. No. 3. Universitas Sam Ratulangi.

Mulyadi. 2016. Sistem Akuntansi Edisi 4. Salemba Empat. Jakarta.

Pontoh, Winston. 2013. Akuntansi Konsep dan Aplikasi. Halaman Moeka. Jakarta.

Rompas, R., Pangemanan, S., dan Kalalo, M. 2018. Evaluasi Efektivitas Pengendalian Intern Sistem Informasi Penggajian RSUP Prof. DR. R. D. Kandou Manado. Jurnal Riset Akuntansi Going Concern Vol. 13. No 2. Universitas Sam Ratulangi.

Salman, R. Kautsar., dan Farid, Mochammad. 2016. Akuntansi Manajemen. Penerbit Indeks. Jakarta.

Samuna, J., Sabijono, H., dan Walandouw, S. 2017. Evaluasi Penerapan Sistem Pengendalian Intern Persediaan Barang Dagang Pada Toko Mahkota Diesel Manado. Jurnal Riset Akuntansi Going Concern Vol. 12. No.1. Universitas Sam Ratulangi.

Susanti, L. Dyna. 2016. Evaluasi Sistem Pengendalian Internal Menggunakan Pendekatan COSO Studi Kasus Koperasi Warga Patra 5. Thesis (Online). Fakultas Ekonomi dan Bisnis Universitas Airlangga. Surabaya.

Tuanakotta, M. Theodurus. 2013. Auditing Berbasis ISA (International Standards On Audting). Salemba Empat. Jakarta.

Turangan, J. C., Saerang, D. P. E., dan Pusung, R. J. 2017. Evaluasi Sistem Pengendalian Internal (Internal Control) Terhadap Kinerja Dinas Pekerjaan Umum Sulawesi Utara. Jurnal Riset Akuntansi Going Concern Vol. 12 No. 2. Universitas Sam Ratulangi.

Tontoli, A. S., Elim, I., dan Tirayoh, V. 2017. Analisis Efektivitas Pengendalian Intern Persediaan Barang Dagang Pada PT. Kimia Farma Apotek 74 Manado. Jurnal Riset Akuntansi Going Concern Vol. 12 No. 2 : 231-240. Universitas Sam Ratulangi. 